\title{
Menyoal Capaian Realisasi Penanaman Modal Dalam Negeri
}

\section{Ecces: \\ Economics Social and Development Studies}

\author{
Edwin Setya Parahita ${ }^{1}$ \\ Junaedi $^{2}$ \\ 1,2 Jurusan Ilmu Ekonomi \\ Universitas Darul 'Ulum Jombang \\ Jl. Abdurahman Wahid 29 A Jombang \\ Email: eparahita@yahoo.com; junaedibinhm@gmail.com
}

(Article history) Received: 2019-11-14, Revised: 2019-11-24, Accepted: 2020-06-19, Available online: 2020-06-23, DOI: $10.24252 /$ ecc.v7i1.11087

\section{Abstrak: Menyoal Capaian Realisasi Penanaman Modal Dalam Negeri}

Capaian realisasi Penanaman Modal Dalam Negeri (PMDN) di Kabupaten Jombang beberapa tahun terakhir tercatat cukup tinggi. Namun diduga bahwa validitas capaian yang tinggi tersebut masih banyak dipertanyakan karena adanya permasalahan penyusunan dan pelaporan data investasi. Penelitian ini bertujuan untuk menganalisis data capaian realisasi penanaman modal dalam negeri (PMDN) di Kabupaten Jombang. Metode yang digunakan adalah penelitian deskriptif dengan pendekatan kualitatif. Data diperoleh dari hasil penelusuran langsung, wawancara, dan laporan realisasi PMDN periode 2010-2018. Hasil penelitian menunjukkan bahwa penyusunan data capaian realisasi PMDN di Kabupaten Jombang diindikasikan terjadi kesalahan prosedur. Pertama, data yang digunakan dalam penyusunan tidak bersumber dari Laporan Kegiatan Penanaman Modal (LKPM). Kedua, penggunaan data perizinan berusaha dalam penyusunan data capaian realisasi PMDN tanpa verifikasi dan validasi ke lapangan. Ketiga, ketidaktelitian dalam mengolah data sehingga terjadi duplikasi dan data tidak valid. Implikasi dari penlitian ini adalah penyusunan data target dan realisasi nilai investasi oleh pemerintah, untuk perencanaan pembangunan agar lebih logis dan berhati-hati dalam proses penyusunannya. Lebih dari itu, penting untuk memperhatikan data investasi yang tampak sangat tinggi, agar lebih presisi dalam menentukan angka nilai riil investasi, dan tidak terjebak dalam angka-angka proyeksi investasi semata.

Kata Kunci: LKPM, Perizinan Berusaha, PMDN, Realisasi 


\section{Abstract: Questioning of Realization Achievement of Domestic Investment}

Achievement of the realization of Domestic Investment (PMDN) in Jombang in recent years recorded quite high. However, it is suspected that the high validity of these achievements is still questionable due to problems in the preparation and reporting of investment data. This study aims to analyze data on the achievement of domestic investment realization (PMDN) in Jombang. The method used is descriptive research with a qualitative approach. Data obtained from direct search results, interviews, and PMDN realization reports for the 20102018 period. The results showed that the preparation of PMDN realization data in Jombang District indicated procedural errors. First, the data used in the preparation did not come from the Investment Activity Report (LKPM). Second, the use of licensing data seeks to compile PMDN realization data achievements without verification and validation to the field. Third, inaccuracy in processing the data resulting in duplication and invalid data. The implication of this research is the preparation of target data and the realization of investment value by the government, for development planning to be more logical and careful in the preparation process. More than that, it is important to pay attention to investment data that appear to be very high, so that they are more precise in determining the real value of investment, which is actually and not trapped in investment projection figures alone.

Keywords: Business Licensing, LKPM, PMDN, Realization.

\section{PENDAHULUAN / INTRODUCTION}

Dalam rangka meningkatkan perekonomian Indonesia, salah satu upaya yang di lakukan oleh pemerintah adalah dengan membuka kesempatan investasi atau penanaman modal. Dengan adanya penanaman modal ini dapat menggerakkan serta meningkatkan pertumbuhan ekonomi, memperbanyak lapangan pekerjaan dan kesempatan kerja, peningkatan pendapatan, dan peningkatan kesejahteraan penduduk. Banyak hasil penelitian yang menyinggung dan mendukung masalah ini, dalam temuan Prasetyo (2009), Asiyan (2013), Aulia (2013), Maharani (2016), Mahrisa dan Syamsul (2019) mengungkapkan bahwa terciptanya barang modal dari kegiatan investasi akan menciptakan faktor produksi dan lapangan kerja baru sehingga siklus perekonomian akan berlangsung kearah yang positif. Investasi menjadi faktor krusial bagi berlangsungnya proses pembangunan ekonomi, dimana pembangunan ekonomi merupakan keterlibatannya kegiatan-kegiatan produksi barang dan jasa di semua sektor ekonomi. Terciptanya kegiatan-kegiatan produksi dapat mendorong terciptanya lapangan pekerjaan sehingga kesempatan kerja penduduk menjadi meningkat yang kemudian akan berimbas pada meningkatnya kesejahteraan masyarakat. 


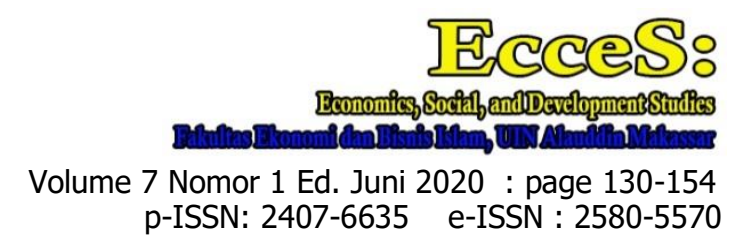

Selaras dengan peranan investasi dalam upaya meningkatkan pertumbuhan ekonomi nasional, maka salah satu komponen dalam menentukan capaian pertumbuhan ekonomi di suatu daerah juga berasal dari sektor penanaman modal. Hal ini berkenaan dengan upaya untuk menciptakan keberlanjutan pertumbuhan ekonomi secara terus-menerus, dimana pertumbuhan ekonomi tidak hanya dapat didorong oleh konsumsi tanpa adanya konstribusi yang berarti dari penanaman modal (Tambunan, 2001).

Kegiatan investasi ini secara umum dapat dibedakan menjadi dua kategori yaitu berupa Penanaman Modal Asing (PMA) dan Penanaman Modal Dalam Negeri (PMDN). Dimana PMA adalah kegiatan pengeluaran atau pembelanjaan barang-barang modal oleh investor untuk menambah kemampuan produksi barang dan jasa yang dilakukan oleh investor asing dengan menggunakan modal asing. Sedangkan PMDN merupakan kegiatan pengeluaran atau pembelanjaan investor atau perusahaan untuk membeli barang-barang produksi, untuk menambah kemampuan memproduksi barang dan jasa yang tersedia dimana investor dan modal yang digunakan berasal dari dalam negeri (Setyowati dan Fatimah, 2007). Penanaman modal yang mampu direalisasikan oleh suatu negara atau daerah, baik berupa PMA ataupun PMDN memegang peranan penting dalam upaya menciptakan pertumbuhan perekonomian serta menggerakan sektor-sektor riil perekonomian baik di tingkat nasional maupun di daerah.

Peningkatan realisasi penanaman modal dan investasi di daerah yang menggairahkan, selalu diupayakan setiap pemerintah daerah dengan menciptakan iklim investasi yang kondusif bagi investor. Iklim investasi adalah semua hal yang terkait dengan lingkungan, kelembagaan dan kebijakan, baik yang saat ini dilaksanakan maupun yang diharapkan dan diprediksikan terjadi di masa datang, yang bisa berpengaruh terhadap risiko dan tingkat pengembalian suatu investasi yang ditanamkan.

Pemerintah Indonesia saat ini telah mengeluarkan beberapa paket kebijakan ekonomi yang terkait upaya meningkatkan investasi melalui percepatan izin berusaha, deregulasi peraturan dan insentif penanaman modal yang kesemuanya diharapkan dapat meningkatkan capaian investasi nasional. Sementara capaian investasi di masing-masing daerah menjadi tugas kepala daerah untuk mewujudkannya, dimana dalam pelaksanaannya harus sinkron dan selaras dengan kebijakan pemerintah pusat dengan tidak membatasi inovasi yang dilakukan oleh masing-masing daerah sepanjang tidak bertentangan dengan aturan yang berlaku. Daerah-daerah di Indonesia dalam pelaksanaan capaian investasinya membentuk kelembagaan penanaman modal yang merupakan kepanjangan tangan dari 
kepala daerah tersebut. Apalagi dengan diterbitkannya Peraturan Menteri Dalam Negeri Nomor 100 Tahun 2016 Tentang Pedoman Nomenklatur Dinas Penanaman Modal dan Pelayanan Terpadu Satu Pintu Provinsi dan Kabupaten atau Kota maka hampir dipastikan seluruh Indonesia nomenklatur kelembagaan yang melaksanakan fungsi-fungsi penanaman modal di daerah adalah sama.

Upaya untuk menciptakan dan mendukung peningkatan iklim investasi kondusif menjadikan faktor kelembagaan menjadi sangat penting peranannya. Karena itu agar proses penanaman modal bisa berjalan efektif dan efisien serta tidak berbelit-belit maka kelembagaan yang terkait dengan penanaman modal dangan kelembagaan yang terkait perizinan harus disatukan. Hal ini dalam upaya menciptakan kemudahan untuk memulai berusaha bagi masyarakat (easy of doing business). Upaya untuk melakukan reformasi kelembagaan penanaman modal dan perizinan telah dilaksanakan oleh pemerintah pusat sejak ditetapkannya UU 25/2007 tentang Penanaman Modal dan sejalan dengan hal tersebut pada tahun 2017 berdasarkan Peraturan Daerah Kabupaten Jombang Nomor 8 Tahun 2016 tentang pembentukan dan susunan perangkat daerah Kabupaten Jombang, pemerintah Kabupaten Jombang menyatukan Organisasi Perangkat Daerah (OPD) yaitu kantor penanaman modal dan PPD Kabupaten Jombang dengan Badan Pelayanan Perizinan Kabupaten Jombang menjadi satu OPD yang dikenal sebagai Dinas Penanaman Modal dan Pelayanan Terpadu Satu Pintu Kabupaten Jombang (DPM PTSP). Dengan perubahan struktur kelembagaan ini diharapkan kinerja investasi di Kabupaten Jombang dapat berjalan optimal.

Menurut data BPS Kabupaten Jombang (2017) capaian realisasi Penanaman Modal Dalam Negeri (PMDN) di Kabupaten Jombang pada periode tahun 2012-2016 menunjukkan tren peningkatan, walaupun pada tahun 2015 terjadi penurunan capaian hingga $28,1 \%$ dari tahun 2015 yaitu dari 389,86 milyar rupiah di tahun 2014 menjadi 280, 23 milyar rupiah di tahun 2015. Akan tetapi di tahun 2016 capaian realisasi PMDN meningkat hingga $115 \%$ persen dari tahun 2015 atau mencapai 603,11 milyar rupiah.

Perlunya kejelasan dalam prosedur pengolahan data dan pencatatan capaian realisasi investasi PMDN ini perlu untuk dicermati karena data tersebut menjadi sumber rujukan pertumbuhan perekonomian di suatu daerah. Hal penting lainnya dari data realisasi capaian realisasi investasi PMDN ini selalu menjadi acuan pembuatan laporan pertanggung jawaban kepala daerah setiap tahunnya yang disampaikan dihadapan DPRD dan menjadi sumber rujukan dari pihak-pihak yang membutuhkan data tersebut untuk digunakan sebagai data pokok indikator perekonomian. Oleh karena itu validitas data capaian realisasi PMDN ini 


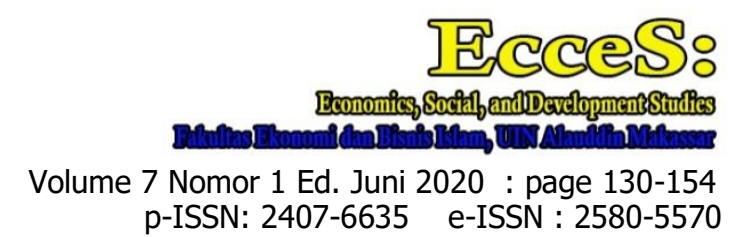

menjadi sangat penting, jangan sampai data yang disampaikan, disusun dan menjadi bahan laporan tersebut belum sesuai dengan kenyataan di lapangan. Bisa jadi data tersebut baru merupakan data bayangan (shadow data) bukan data nyata (real data) jumlah investasi yang telah ditanamkan investor untuk usaha yang dijalankan. Data bayangan yang dimaksudkan ini kemungkinan bisa merupakan angka proyeksi investasi, angka perkiraan investasi dan angka pendeklarasian investor. Apabila data bayangan ini digunakan sebagai basic data dalam penyusunan capaian realisasi PMDN maka dapat dipastikan tingkat validitasnya rendah dan sangat absurd apabila data bayangan sebagaimana dimaksudkan di atas digunakan sebagai data utama dalam laporan capaian realisasi investasi PMDN di suatu daerah.

Berdasarkan latar belakang tersebut maka artikel ini berupaya menganalisis bagaimana data capaian realisasi penanaman modal dalam negeri di Kabupaten Jombang yang meliputi cara mendapatkan data capaiannya, proses capaiannya, metode penyusunan dan metode pelaporan data capaian, dan kriteria dalam penyusunan data capaian. Dengan analisis capaian realisasi ini akan diketahui apakah capaian relaisasi investasi ini benar-benar realistis atau tidak, valid atau tidak.

\section{TINJAUAN TEORITIK / LITERATURE REVIEW}

Adam Smith dalam Skousen (2009) secara teguh dan konsisten mempertahankan teorinya bahwa aktivitas ekonomi mesti diserahkan dalam mekanisme pasar, permintaan akan menciptakan penawarannya sendiri, termasuk masuknya investasi dalam sebuah negara. Hal itu secara teknikal dapat diwujudkan dengan kebijakan harga alamiah yang harus dibiarkan berlaku sesuai dengan mekanisme pasar. Harga alamiah akan berlaku tanpa perlu dibakukan oleh penguasa sipil. Apa yang akan dibakukan oleh pemerintah bukanlah harga alamiah atau harga yang fair, tetapi harga yang pada akhirnya hanya akan menguntungkan segelintir orang yang kaya dan berkuasa dan bukannya menguntungkan semua pihak. Karena itu, jalan terbaik untuk bisa mewujudkan harga yang fair adalah dengan membiarkan harga alamiah berkembang sesuai dengan mekanisme pasar.

Namun gagasan itu ditentang Keynes dalam Deliarnov (2010) bahwa apa yang disarankan Smith tentang permintaan menciptakan penawarannya sendiri justru tidak terbukti dengan mekanisme pasar. Pasar tidak bekerja secara bebas, tapi butuh regulasi dan intervensi pemerintah untuk menciptakan keseimbangan di dalam pasar, yaitu dengan jalan 
pengeluaran pemerintah untuk membeli barang-barang modal dan peralatan-peralatan produksi dengan tujuan untuk mengganti dan terutama menambah barang-barang modal yang akan digunakan untuk memproduksi barang dan jasa di masa yang akan datang. Investasi adalah suatu komponen dari $\mathrm{PDB}=\mathrm{C}+\mathrm{I}+\mathrm{G}+(\mathrm{X}-\mathrm{M})$. Investasi adalah penanaman modal untuk satu atau lebih aktiva yang dimiliki dan biasanya berjangka waktu lama dengan harapan mendapatkan keuntungan di masa-masa yang akan datang.

Lebih lanjut Harrod-Domar dalam Mankiw (2012) mencoba menengahi perdebatan teoritik itu bahwa peranan pertumbuhan modal dalam menciptkan pertumbuhan ekonomi. Teori Harrod-Domar memandang bahwa pembentukan modal dianggap sebagai pengeluaran yang akan menambah kemampuan suatu perekonomian untuk menghasilkan barang dan/atau jasa, maupun sebagai pengeluaran yang akan menambah permintaan efektif seluruh masyarakat. Dimana apabila pada suatu masa tertentu dilakukan sejumlah pembentukan modal, maka pada masa berikutnya perekonomian tersebut mempunyai kemampuan untuk menghasilkan barang-barang dan/atau jasa yang lebih besar.

Pembentukan modal merupakan pokok persoalan pembangunan yang membedakan antara negara sedang berkembang dengan negara maju. Meningkatkan kapasitas negaranegara sedang berkembang untuk mengalihkan sebagian dari sumberdaya yang tersedia untuk kepentingan peningkatan cadangan modal untuk menjamin peningkatan output yang bisa dikonsumsi di masa datang, dan menurunkan rasio kenaikan modal output menjadi fokus utama para perencana pembangunan. Secara empiris cukup banyak temuan yang mendukung teori Harrord-Domar, Nurkse maupun Lewis. Misalnya Haryanto (2005) yang menyimpulkan bahwa kunci utama untuk mencapai peningkatan pertumbuhan ekonomi yang tercermin dari kemampuannya meningkatkan laju pertumbuhan dan tingkat pendapatan. Semakin besar tingkat investasi maka semakin besar pula tingkat pertumbuhan ekonomi yang bisa dicapai. Demikian juga dengan penelitian Humaini et. al. (2007); Setyowati dan Fatimah (2007); Prasetyo (2009); Asiyan (2013); Aulia (2013); Malau, et. al. (2015); Maharani (2016); serta Mahrisa dan Syamsul (2019).

\section{METODE PENELITIAN / METHODS}

Metode yang digunakan dalam penelitian ini adalah kualitatif, sebagaimana yang diungkapkan Raco (2013) bahwa metode kualitataif merupakan pendekatan untuk mengeksplorasi dan memahami suatu fenomena. Penelitian kualitatif yang digunakan adalah kualitatif deskriptif dengan pendekatan studi kasus, yang bertujuan untuk mengungkapkan 


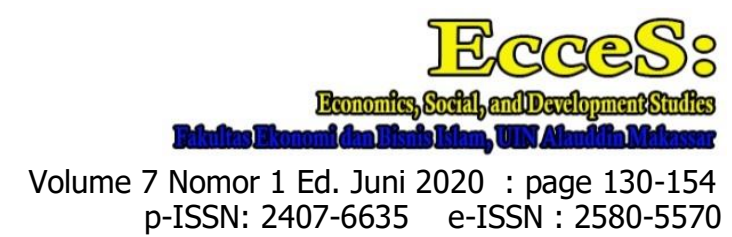

suatu masalah atau keadaan tertentu sebagaimana adanya sehingga dapat memberikan gambaran secara tetap tentang keadaan yang sebenarnya dari objek yang diteliti dalam rangka memecahkan masalah tertentu yang spesifik. Dalam penelitian ini, peneliti terlibat langsung di dalam kondisi atau obyek yang sedang diteliti. Metode wawancara dan observasi menjadi cara utama dalam penelitian ini. Variabel-variabel atau faktor yang digunakan dalam penelitian ini antara lain; faktor predisposisi yang diasumsikan dapat mempengaruhi data capaian realisasi Penanaman Modal Dalam Negeri (PMDN) di Kabupaten Jombang, faktor pendukung merupakan pendukung terlaksananya penyusunan data capaian realisasi PMDN di Kabupaten Jombang, faktor penguat merupakan faktor pendorong tersusunnya data capaian realisasi PMDN di Kabupaten Jombang.

Sementara itu untuk instrumennya adalah peneliti sendiri yang bertindak sebagai penggali data melalui pengamatan atau observasi, pengumpulan data dan dokumentasi serta melakukan pendalaman kajian melalui wawancara pada sumber data dan obyek yang akan diteliti. Dalam penelitian ini, data primer diperoleh peneliti dari kegiatan wawancara dengan pihak-pihak yang terlibat secara langsung dengan tugas terkait pembuatan pendataan PMDN, yaitu pejabat struktural dan staf Dinas Penanaman Modal dan Pelayanan Terpadu Satu Pintu (DPM PTSP) Kabupaten Jombang. Awal wawancara ada empat orang sebagai narasumber kunci yang terkait dengan tugas tersebut. Sedangkan data sekunder bersumber dari dokumen-dokumen resmi, catatan-catatan, serta arsip pada DPM PTSP Kabupaten Jombang yang berkaitan dengan fokus penelitian. Alasan utama peneliti mengambil lokasi di Kabupaten Jombang adalah karena Pemerintah Kabupaten Jombang telah menyusun laporan perkembangan Capaian PMDN setiap tahunnya, dengan capaian yang termasuk kategori tinggi di Jawa Timur, yaitu peringkat kedua setelah Surabaya, meskipun Jombang bukan ketegori kota besar.

Setelah semua data terkumpul maka dilakukan pengujian terhadap keabsahan data. Keabsahan data disini sangatlah penting untuk menjamin validitas sebuah data. Dalam penelitian ini, peneliti menggunakan triangulasi, yaitu teknik pemeriksaan keabsahan data yang memanfaatkan sesuatu yang lain selain data itu sebagai data pembanding (Moleong, 2005). Sedangkan teknik analisis data yang digunakan adalah dengan menggunakan model interaktif. Dalam model analisis ini terdapat tiga komponen analisis, yaitu: reduksi data, salinan data dan penarikan kesimpulan (Miles dan Huberman, 2007). 


\section{HASIL DAN PEMBAHASAN / DISCUSSION}

\section{Mekanisme Penetapan Capaian Realisasi PMDN}

Tidak terdapatnya data capaian realisasi penanaman modal dalam sistem LKPM online untuk Kabupaten Jombang membuat bidang pengolah data dan sistem informasi hanya memperoleh satu masukan sumber data yaitu data perizinan berusaha yang disampaikan oleh bidang penyelenggaraan pelayanan perizinan. Keterbatasan dalam sumber data dalam penyusunan realisasi PMDN ini menjadikan kendala untuk penyusunan laporan realisasi PMDN karena data yang didapatkan bukan merupakan data realisasi PMDN akan tetapi data perizinan berusaha. Dalam data perizinan berusaha meskipun terdapat besaran modal usaha yang disampaikan oleh penanaman modal akan tetapi hal tersebut tidak menggambarkan realisasi penanaman modal yang disampaikan.

Laporan realisasi penanaman modal merupakan amanah yang harus disusun dan dipublikasikan untuk itu dalam penyusunan harus detail, cermat dan kredibel. Akan tetapi karena tidak adanya proses verifikasi ulang terhadap pelaku penanam modal yang memproses perizinan berusaha maka data tersebut memiliki relevansi yang tinggi terhadap capaian realisasi PMDN. Argumentasi pemakaian data perizinan berusaha sebagai data capaian realisasi penanaman modal mengacu pada ketentuan pasal 3 Peraturan Menteri Perdagangan Republik Indonesia Nomor 36/M-DAG/PER/9/2007 tentang Penerbitan Surat Izin Usaha Perdagangan dimana disebutkan bahwa: "perusahaan dengan modal dan/atau kekayaan bersih". Dari ketentuan ini menjadi acuan bahwa modal yang disampaikan dalam pengajuan perizinan berusaha (SIUP) merupakan besaran penanaman modal yang ditanamkan untuk menjalankan usaha.

Berkenaan dengan hal tersebut maka sejak tahun 2010 disusunlah capaian realisasi PMDN di Kabupaten Jombang atas dasar permohonan pengajuan SIUP dengan membagi kedalam 18 sektor bidang usaha. Metode pembagian sektor bidang usaha ini didasarkan atas barang atau jasa dagangan utama yang terdapat dalam SIUP. Petugas di Bidang Pengolahan Data dan Sistem Informasi melakukan sorting terhadap data softfile rekapitulasi permohonan berusaha dan mengumpulkan penanam modal kedalam 18 sektor bidang usaha.

Hasil proses sorting yang dilakukan adalah dengan melakukan proses filter terhadap softfile yang diperoleh dari Bidang Penyelenggaraan Pelayanan Perizinan. Proses filter yang dilakukan rawan terjadinya duplikasi data karena dalam sebuah perusahaan penanaman modal bisa jadi dan sangat dimungkinkan melakukan kegiatan usaha lebih dari satu bidang 
usaha. Dengan proses filterisasi yang tidak cermat maka akan terjadi pencatatan penanaman modal ganda, yaitu penanam modal dicatatkan penanaman modalnya di satu sektor usaha dan juga lainnya. Dengan metode ini maka didapatkan laporan capaian realisasi PMDN di Kabupaten Jombang. Data tersebut digunakan oleh Badan Pusat Statistik (BPS) sebagai laporan statistik daerah maupun oleh pemangku kebijakan sebagai laporan pertanggungjawaban tahunan.

Selama periode tahun 2010-2018 didapatkan bahwa terdapat 17.127 perusahaan penanaman modal dengan total jumlah investasi yang ditanamkan sebesar Rp. 7.786.694.970.619.- adapun jumlah tenaga kerja yang dapat diserap adalah sejumlah 107.871 orang. Perkembangan capaian realisasi Penanaman Modal Dalam Negeri di Kabupaten Jombang pada 2010-2018 dapat di lihat pada gambar berikut:

Gambar 1. Perkembangan Penanaman Modal Dalam Negeri (PMDN) Periode 2010-2018

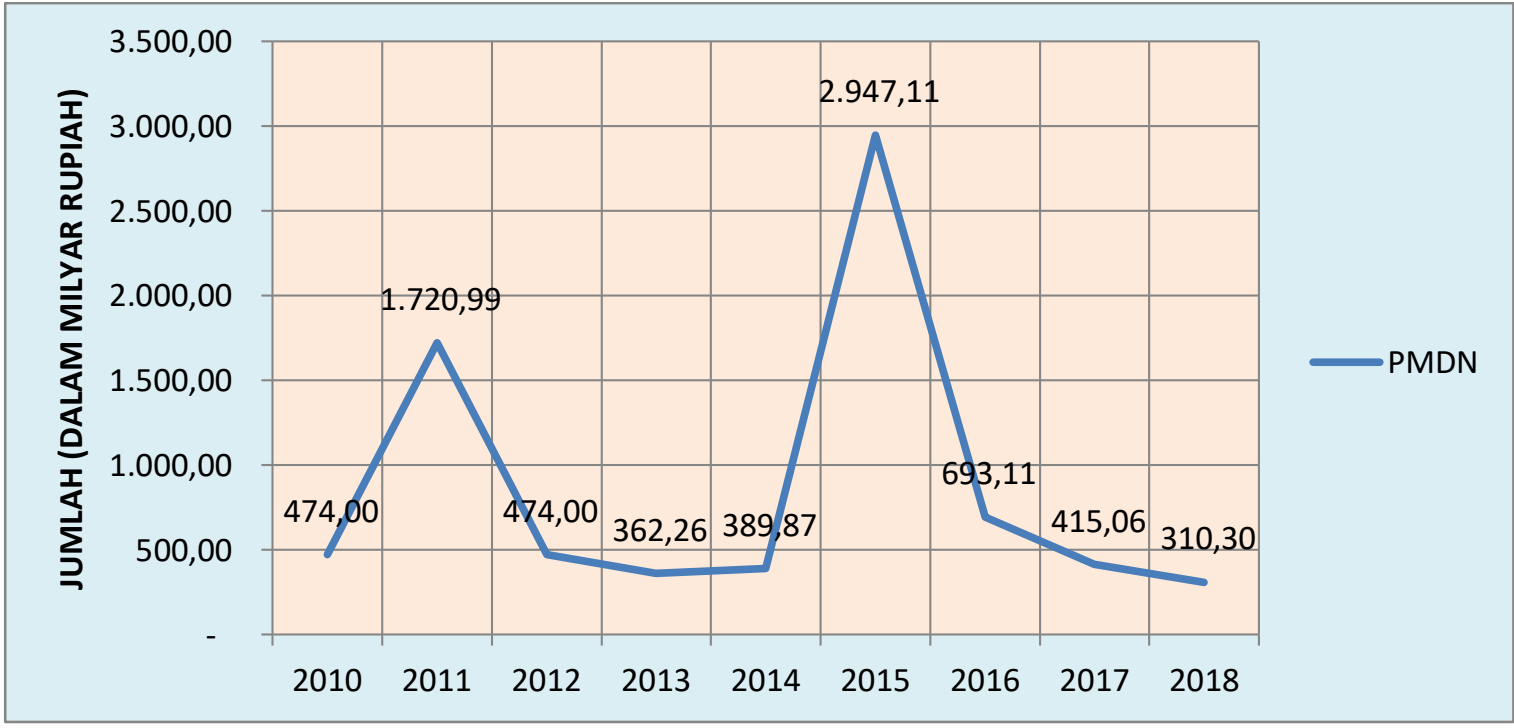

Sumber: Hasil Pengolahan Data Capaian Realisasi PMDN Kabupaten Jombang

Perkembangan PMDN di Kabupaten Jombang sebagaimana ditunjukkan dalam Gambar tersebut diperoleh bahwa pada 2015 merupakan tahun dimana realisasi PMDN di Kabupaten Jombang mencapai titik tertinggi dengan mencapai realisasi 2,9 triliun rupiah dan pada 2018 menjadi tahun dimana realisasi PMDN mencapai titik terendah dengan hanya sebesar 310 milyar rupiah. Dari gambar itu juga dapat diperoleh bahwa perkembangan realisasi PMDN di Kabupaten Jombang cenderung stabil pada kisaran angka 300-400 milyar rupiah tiap tahunnya. 
Capaian realisasi PMDN dalam rentang 2010-2018 setidaknya menyerap tenaga kerja sejumlah 107.871 orang atau rerata tiap tahunnya sejumlah 11.986 orang. Gambar berikut menunjukan perkembangan serapan tenaga kerja dari hasil capaian realisasi PMDN di Kabupaten Jombang.

Gambar 2. Perkembangan Penyerapan Tenaga Kerja dari Capaian PMDN Periode 2010-2018

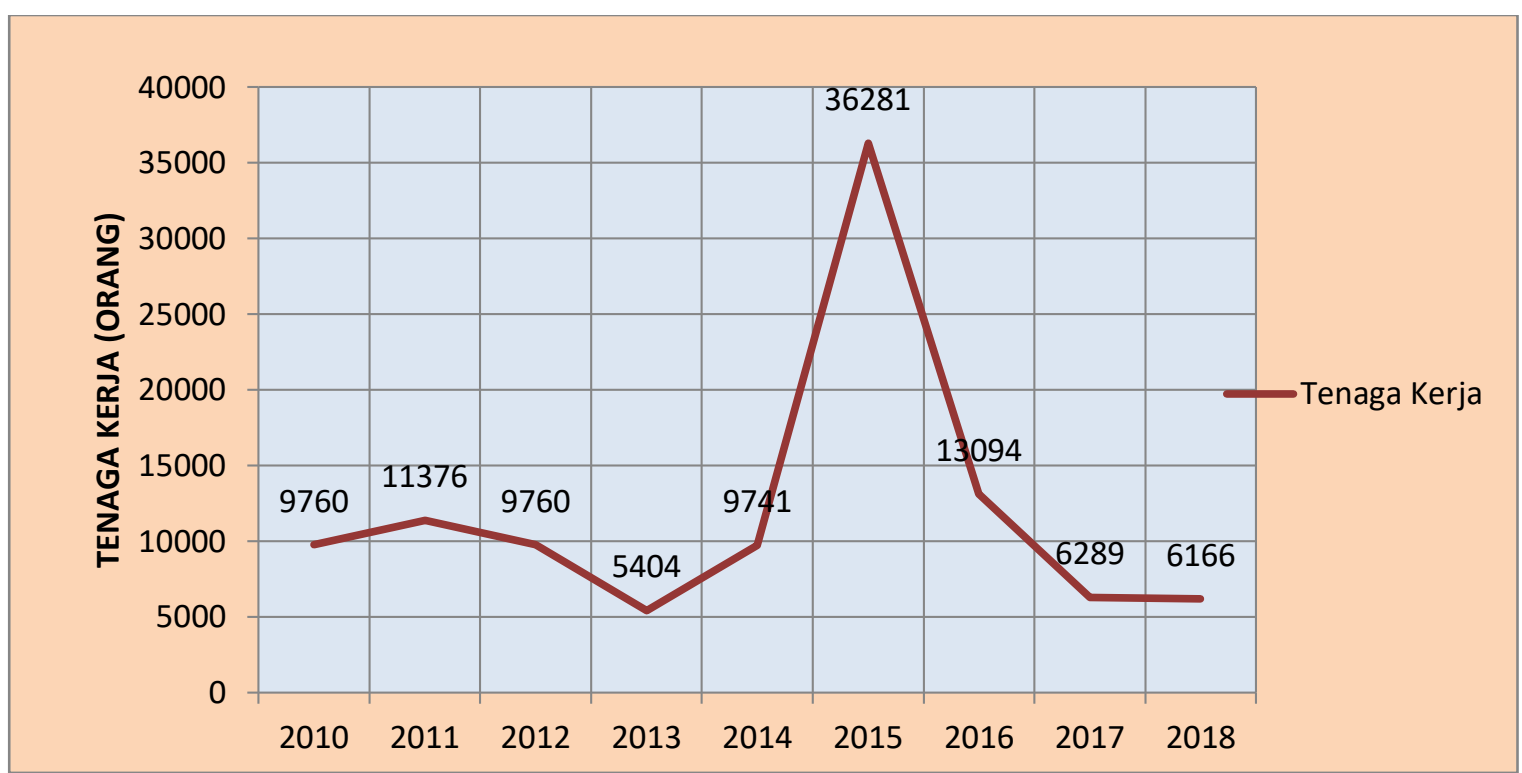

Sumber: Hasil Pengolahan Data Capaian Realisasi PMDN Kabupaten Jombang

Selaras dengan capaian realisasi PMDN dimana pada 2015 menjadi titik tertinggi maka pada 2015 serapan tenaga kerja mencapai titik tertinggi pula. Pada 2015 sejumlah 36.281 tenaga kerja dapat terserap dari 18 sektor bidang usaha penanaman modal. Jumlah tenaga kerja yang terserap tersebut melonjak lebih dari 350 persen apabila dibandingkan 2014. Pada 2013 merupakan fase dimana penyerapan tenaga kerja dari capaian realisasi PMDN menjadi titik terendah yaitu sebesar 5.404 tenaga kerja yang terserap. Hal ini tentu berbeda dengan hasil capaian realisasi PMDN, dimana pada tahun 2018 merupakan tahun dengan capaian realisasi PMDN terendah.

Capaian realisasi PMDN periode 2010-2018 diperoleh dari 17.127 unit usaha yang melakukan penanaman modal pada 18 bidang usaha. Rata-rata tiap tahun terdapat 1.903 unit usaha penanaman modal yang memberikan kontribusi terhadap capaian realisasi PMDN di Kabupaten Jombang. Unit usaha yang berkontribusi dalam capaian realisasi PMDN tersebut dapat berupa perusahaan berbentuk perorangan (UD, toko dan sejenisnya), perusahaan berbadan usaha (CV, Firma dan sejenisnya) dan perusahaan berbadan hukum 
(PT, koperasi, yayasan dan sejenisnya). Berikutnya menggambarkan perkembangan unit usaha PMDN di Kabupaten Jombang periode 2010-2018.

Gambar 3. Perkembangan Unit Usaha dari Capaian PMDN Periode 2010-2018

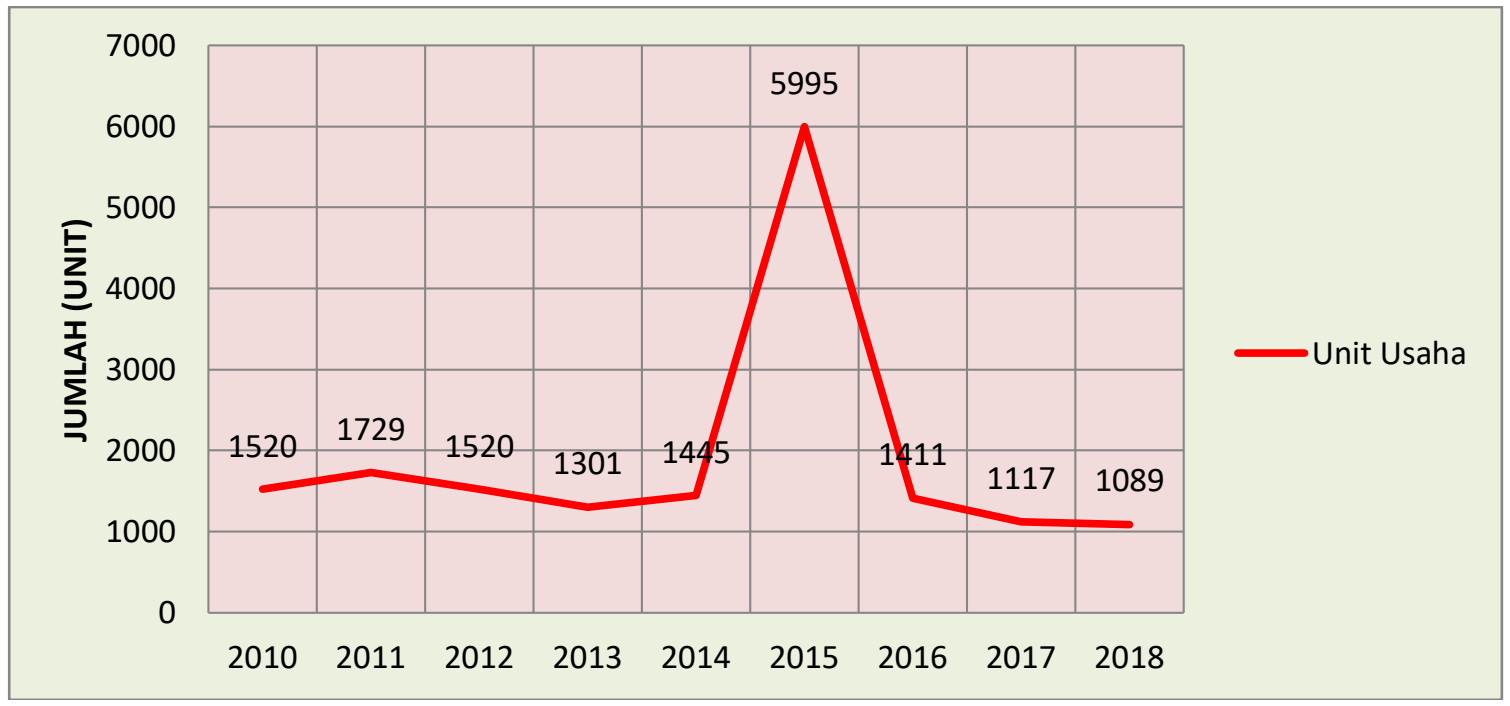

Sumber: Hasil Pengolahan Data Capaian Realisasi PMDN Kabupaten Jombang

Pada 2015 menjadi fase dimana pertumbuhan unit usaha PMDN menjadi penyumbang terbesar dalam capaian realisasi PMDN pada 2010-2018 yaitu sebesar 5.995 unit usaha. Dengan jumlah 1.089 unit usaha penanaman modal yang dapat direalisasi pada 2018 menjadikan tahun tersebut merupakan titik terendah dalam fase perkembangan unit usaha.

Uraian terkait dengan perkembangan PMDN di Kabupaten Jombang yang secara umum berdampak positif terhadap pertumbuhan ekonomi, usaha atau aktivitas ekonomi, dan penyerapan tenaga kerja tentu hal ini sejalan dengan banyak studi yang menyoroti arti pentingnya PMDN terhadap perekonomian suatu Negara ataupun daerah. Misalnya dengan kajian Prasetyo (2009) yang mengemukakan bahwa terdapat hubungan positif antara pembentukan penanaman modal dengan pertumbuhan ekonomi pada suatu negara. Sejalan dengan hal tersebut dalam pasal 3 ayat (2) UU PM diterangkan bahwa terdapat beberapa arti penting penanaman modal, termasuk didalamnya adalah PMDN dalam kegiatan dan perkembangan perekonomian Indonesia, yaitu: meningkatkan kemampuan daya saing dunia usaha nasional; meningkatkan pembangunan ekonomi berkelanjutan; meningkatkan kapasitas dan kemampuan teknologi nasional; menciptakan lapangan pekerjaan; mengolah 
ekonomi potensial menjadi ekonomi riil; mendorong pengembangan ekonomi kerakyatan; dan meningkatkan kesejahteraan masyarakat.

Demikian juga riset Setyowati dan Fatimah (2007) yang menunjukan bahwa dalam jangka pendek capaian investasi dalam negeri tahun sebelumnya sangat berpengaruh terhadap capaian investasi dalam negeri tahun berikutnya dan untuk estimasi jangka panjang variabel yang signifikan berpengaruh terhadap investasi dalam negeri adalah tingkat suku bunga. Hasil ini diperoleh dari hasil kajian yang dilakukan di Provinsi Jawa Tengah pada periode tahun 1980-2002 terhadap faktor-faktor yang mempengaruhi investasi dalam negeri di provinsi tersebut.

Sementara itu Asiyan (2013) menyimpulkan bahwa secara simultan terdapat pengaruh signifikan antara PMDN dan PMA dan ekspor terhadap pertumbuhan ekonomi di Jawa Timur. Ini berarti keberadaan investasi (termasuk didalamnya PMDN) merupakan salah satu faktor yang dapat meningkatkan pertumbuhan ekonomi di suatu wilayah ataupun negara. Jika iklim investasi yang dilanjutkan dengan capaian realisasi investasi berjalan dengan kondusif dan baik, maka dapat dipastikan hal tersebut dapat meningkatkan pertumbuhan ekonomi. Hal ini juga sejalan dengan hasil penelitian yang dilakukan Aulia (2013) Maharani (2016) maupun Mahrisa dan Syamsul (2019) menunjukkan bahwa penanaman modal dalam negeri mempunyai pengaruh positif dan signifikan terhadap pertumbuhan perekonomian. Sedangkan Humaini el al. (2007) menyimpulkan bahwa penanaman modal dalam negeri berpengaruh signifikan terhadap pertumbuhan ekonomi pertumbuhan ekonomi Provinsi Jambi.

Namun demikian ada beberapa kajian yang sedikit berbeda atau tidak sejalan, misalnya Candra (2012) menyatakan bahwa variabel PMDN berpengaruh positif namun tidak signifikan pengaruhnya terhadap pertumbuhan ekonomi. Demikian juga dengan penelitian yang dilakukan oleh Mokodompis, et al (2014), dimana PMDN berpengaruh positif namun tidak signifikan terhadap PDRB. Demikian juga dengan penelitian Cahyono dan Siska (2017) menunjukan bahwa penanaman modal dalam negeri Jawa Timur tidak berpengaruh terhadap pertumbuhan ekonomi Kota Surabaya dan Kabupaten Banyuwangi. Hal yang tak jauh berbeda juga dengan penelitian Prasetyo (2011) yang mengatakan bahwa PMDN mempunyai pengaruh negatif dan tidak siginifkan. Sementara Yunarko (2007) menunjukkan bahwa investasi tidak berpengaruh signifikan terhadap pertumbuhan ekonomi Jawa Tengah, hal ini diakibatkan karena proses perijinan yang sangat rumit di sehingga menyebabkan ekonomi biaya tinggi (high cost economy). 


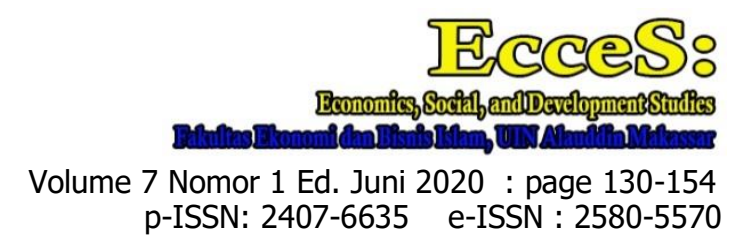

Merujuk hasil riset tersebut, meskipun ada yang berbeda namun secara umum dapat disimpulkan bahwa PMDN sangat penting dalam rangka upaya untuk meningkatkan perekonomian di suatu wilayah dimana efek keberlanjutannya adalah mendorong penurunan angka kemiskinan di wilayah tersebut. Modal memegang peranan penting dalam upaya pembangunan ekonomi, cepat atau lambatnya pertumbuhan ekonomi dan bergairahnya pembangunan ekonomi suatu daerah terjadi karena akumulasi modal yang berputar di suatu wilayah. Dimana akumulasi modal yang dihimpun merupakan investasi atau penanaman modal yang dapat digunakan untuk mendatangkan peralatan, membangun sejumlah gedung, mengembangkan teknologi dan kegiatan pembangunan lainnya yang berguna dalam rangka kegiatan produktif. Sehingga dari rangkaian kegiatan ini didapatkan peningkatan atau penambahan output potensial daerah dan peningkatan pertumbuhan ekonomi jangka panjang.

\section{Analisis Data Capaian Realisasi PMDN Periode 2010-2018}

Data capaian realisasi secara sederhana menurut Vercellis (2011) dapat dimaknai sebagai suatu file yang berisi hasil pelaksanaan kegiatan. Dimaksudkan file di sini adalah bentuk dokumen baik berupa hardcopy maupun digital yang menjadi sumber untuk menyusun laporan. Adapun pelaksanaan kegiatan adalah rangkaian proses untuk mengumpulkan, menverifikasi dan menyusun laporan. Sehingga apabila diselaraskan dengan bentuk penelitian yang dilakukan maka semua proses ini adalah yang terkait dengan kegiatan Penanaman Modal Dalam Negeri (PMDN).

Realisasi dapat diwujudkan dengan hasil kerja atau capaian dari kegiatan atau program yang telah direncanakan sebelumnya, adapun sasaran dan tujuan realisasi telah ditetapkan oleh suatu organisasi. Pelaksanaan realisasi mengikuti periode waktu tertentu dan dalam proses untuk mencapainya dipengaruhi oleh beberapa faktor. Efektivitas capaian realisasi khususnya di Indonesia menurut Keban (2004) dipengaruhi beberapa faktor: (a) Adanya kejelasan ketentuan hukum dan peraturan perundang-undangan; (b) Manajemen sumberdaya manusia yang kredibel; (c) Adanya keselarasan dan kesesuaian antara paradigma yang dianut oleh manajemen suatu organisasi dengan tujuan capaian realisasi; dan (d) Komitmen yang kuat dari pimpinan organisasi publik terhadap pentingnya mendapatkan data yang akurat.

Terlepas dari usaha meningkatkan capaian realisasi investasi yang dilaksanakan oleh pemerintah ternyata terdapat permasalahan mendasar berkenaan dengan ketersediaan regulasi yang dapat memberikan jaminan kepastian hukum kepada calon investor atau 
investor. Kepastian hukum merupakan syarat mutlak agar dalam pelaksanaan penanaman modal yang dilakukan mendapatkan jaminan dan tidak menimbulkan pesimistis di kalangan investor. Kepastian hukum dalam berinvestasi ini seharusnya menjadi perhatian serius dari pemangku kebijakan. Menurut Abib et. al (2016) seringkali terjadi tumpang tindih dan tidak singkronnya peraturan penanaman modal sehingga penanaman modal tidak dapat berlangsung optimal.

Selama 2010-2018 data capaian realisasi PMDN di Kabupaten Jombang bersumber dari pengajuan permohonan izin berusaha yang berproses di Dinas Penanaman Modal dan Pelayanan Terpadu Satu Pintu Kabupaten Jombang. Dari hasil pengolahan data yang dilakukan didapatkan 3 informasi utama dalam capaian realisasi PMDN yaitu jumlah unit usaha, PMDN, dan besaran tenaga kerja yang terserap. Gambaran fluktuasi ketiga informasi tersebut dapat dilihat dalam gambar berikut:

Gambar 4. Capaian Realisasi PMDN Periode 2010-2018

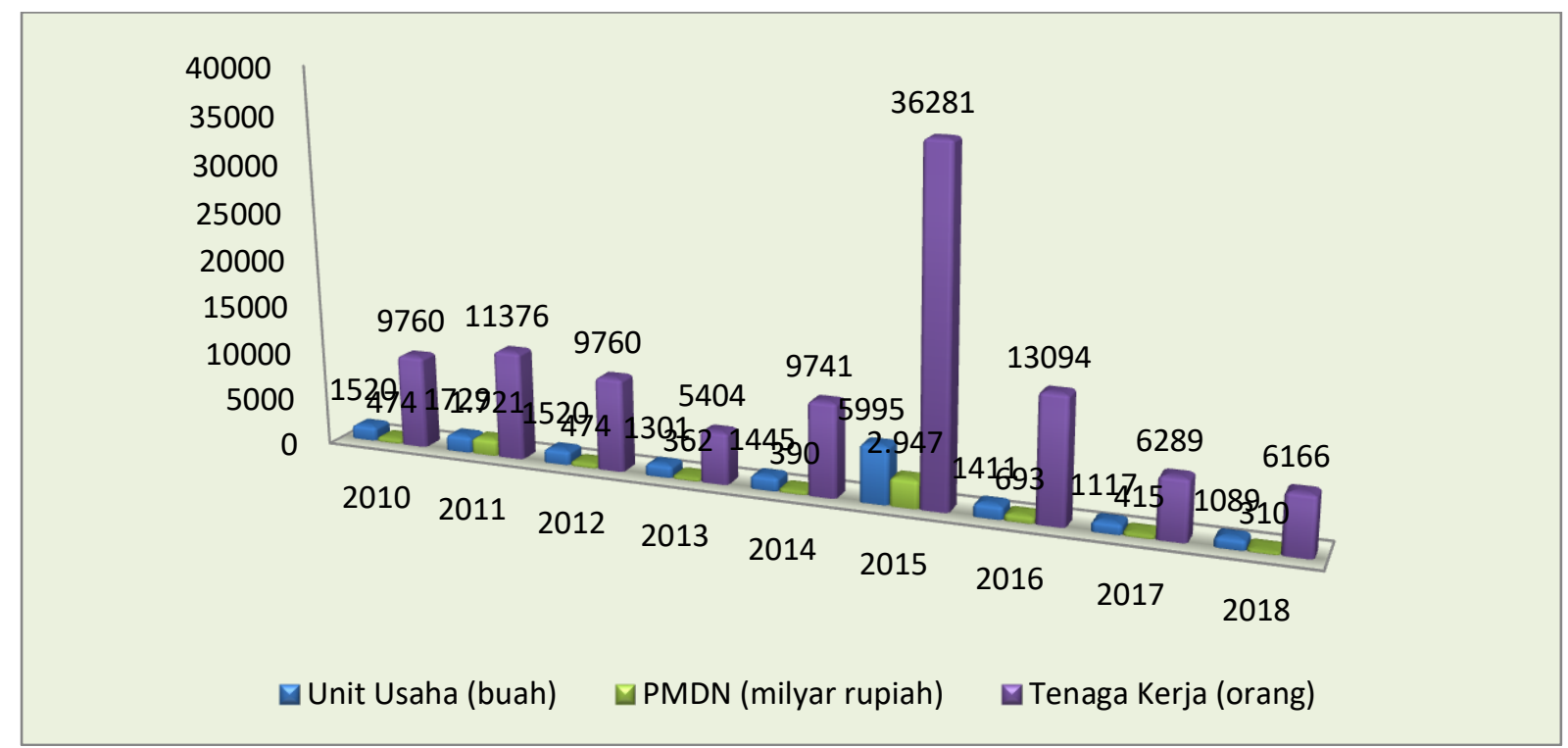

Sumber: Hasil Pengolahan Data Capaian Realisasi PMDN Kabupaten Jombang

Pada tahun 2015 menjadi tahun dimana capaian realisasi PMDN di Kabupaten Jombang mencapai nilai tertinggi dan pada 2018 menjadi tahun dimana capaian realisasi PMDN mendapatkan nilai terendah. Pencapaian realisasi PMDN pada 2015 yang tertinggi selama periode 2010-2018 menjadi menarik untuk dianalisis yang melatarbelakangi hal tersebut bisa terjadi. Secara umum faktor kualitatif yang menjadi penyebab tingginya realisasi PMDN pada 2015 adalah jumlah penanam modal yang melakukan investasi di Kabupaten Jombang sangatlah besar. Hal ini bisa dilihat dari jumlah unit usaha yang ada. 


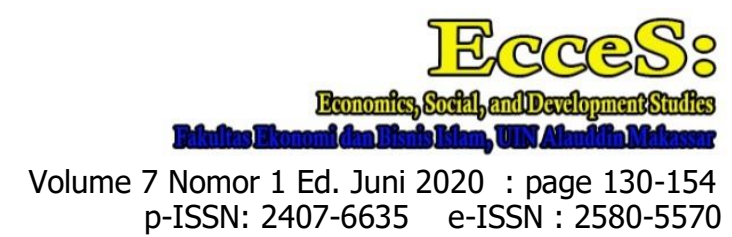

Faktor berikutnya yang berpengaruh adalah perpindahan pabrik atau unit usaha dari daerah ring 1 (Upah Minimum Provinsi yang tinggi) ke Kabupaten Jombang. Perpindahan pabrik dari daerah ring 1 dilatarbelakangi besarnya UMP sehingga pengusaha akan lebih kompetitif jika berinvestasi di Kabupaten Jombang. Dari hasil penelusuran data perusahaan yang dilakukan melalui proses pengunduhan dari aplikasi SIMYaniz setidaknya terdapat beberapa perusahaan/penanam modal yang sebelumnya berada di daerah ring 1 kemudian mendirikan usaha di Kabupaten Jombang.

Penanam modal yang memindahkan investasi ke Kabupaten Jombang beberapa yang terbesar seperti PT. Trijaya Admix di Desa Kertorejo Kecamatan Ngoro yang bergerak di industri konstruksi, PT. Terang Mandiri Hanjaya di Desa Betek Kecamatan Mojoagung bergerak di industri alas kaki, PT. Sari Agro Solution di Desa Betek Kecamatan Mojoagung bergerak di bidang industri bahan kimia, PT. Gemilang inti Sukses yang bergerak di industri pemotongan dan pengepakan unggas dan beberapa perusahaan atau penanam modal yang tidak dapat disebutkan satu persatu. Selain penanam modal dari luar daerah Kabupaten Jombang, juga terdapat penanaman modal lokal yang menanamkan modalnya diantaranya yang terbesar antara lain CV. Wahana Sejahtera Foods di Desa Mojokrapak Kecamatan Tembelang yang bergerak di industri pemotongan dan pengepakan unggas, PT. Karya Mekar Dewatamali yang melakukan perluasan usaha di Kelurahan Jelakombo, Kecamatan Jombang bergerak di industri alas kaki, PT. Samudera Gemilang Plastindo di Desa Balongbesuk Kecamatan Diwek yang bergerak di industri plastik.

Adanya penanaman modal dalam jumlah besar tersebut secara otomatis dapat mendongkrak capaian realisasi PMDN di Kabupaten Jombang khususnya yang terjadi pada 2015. Hal ini tentu sejalan dengan Soesilo dalam Nagi (2005), bahwa untuk mendapatkan hasil pekerjaaan (capaian/realisasi) yang efektif, terdapat beberapa faktor-faktor yang berpengaruh dalam organisasi atau lembaga tersebut yaitu struktur organisasi, kebijakan pengelolaan, sumberdaya manusia, sistem informasi manajemen, dan ketersediaan sarana dan prasarana yang layak. Begitu juga dengan penelitian lain, misalnya Ambarita (2012) Ilham (2013) dan Saleh, et al (2014), yang juga menekankan pada efektifikas capaian investasi maupun efesiensi investasi di suatu wilayah dengan memperhatikan banyak faktor, salah satunya dengan melihat indikator nilai Incremental Capital Output Ratio atau ICOR. Selain itu hasil penelitian Yunarko (2007) menunjukkan bahwa proses perijinan yang sangat rumit di Jawa Tengah menyebabkan ekonomi biaya tinggi sehingga berpengaruh pada tingkat investasi dan hasilnya. 
Namun demikian, hasil pengolahan data realisasi PMDN pada 2015 yang diselenggarakan oleh DPM PTSP Kabupaten Jombang tersebut terdapat beberapa penyimpangan yang dampaknya sangat signifikan terhadap hasil laporan capaian realisasi PMDN. Penyimpangan tersebut diantaranya:

1. Pendataan ulang realisasi PMDN tahun sebelumnya di tahun berjalan.

Perusahaan penanam modal telah melaksanakan realisasi PMDN apabila telah operasional. Perusahaan yang telah beroperasional dan telah melakukan pelaporan realisasi PMDN di tahun berjalan maka di tahun berikutnya hanya berkewajiban melaporkan kegiatan operasional yang sedang berjalan. Laporan kegiatan operasional di tahun berjalan inilah yang menjadi nilai untuk dimasukan kedalam laporan realisasi PMDN. Perusahaan yang mendaftarkan ulang izin usahanya dikarenakan habis masa berlakunya, dipersyaratkan untuk melampirkan total investasi yang telah dilakukan. Total investasi ini merupakan nilai akumulasi dari keseluruhan investasi yang telah dilakukan selama berjalan dan operasionalnya perusahaan. Jika nilai tersebut dimasukkan dalam realisasi PMDN pada tahun berjalan maka tingkat validasinya sangat diragukan.

Pencermatan yang dilakukan terhadap proses pengolahan data realisasi PMDN yang dilakukan oleh DPM PTSP Kabupaten Jombang khususnya pada tahun 2015, didapatkan anomoli berkenaan dengan pengulangan data PMDN sebuah perusahaan. Sebagai hasil uji petik terhadap hasil pengolahan data tersebut adalah dimasukkannya PT. Perkebunan Nusantara X (Persero) PG. Djombang Baru dalam hasil realisasi PMDN. Sebagaimana dimaklumi PG. Djombang Baru tidaklah mungkin berdiri di tahun 2015, sehingga kepentingan perusahaan di tahun 2015 adalah dalam rangka pendaftaran ulang perusahaan. Akan tetapi di tahun 2015, data rekapitulasi penanaman modal perusahaan tersebut dilakukan proses pendataan ulang sehingga masuk dalam laporan realisasi PMDN yang dilakukan oleh DPM PTSP Kabupaten Jombang. Hasil screenshot pengunduhan database izin berusaha dari aplikasi SIMYaniz pada 2015.

2. Penanaman Modal belum operasional namun sudah di data realisasi PMDN nya.

Penanam modal dalam proses untuk mendapatkan fasilitas fiskal dan bea masuk dari negara membutuhkan legalitas berupa izin usaha yang telah diterbitkan sebagai persyaratan. Untuk itu perusahaan mendaftarkan usahanya untuk memperoleh izin di DPM PTSP Kabupaten Jombang. Sebagaimana penjelasan terdahulu bahwa dalam memperoleh izin usaha tersebut perusahaan akan mendeklarasikan nilai penanaman modal yang akan direalisasikan terkait usaha yang dilakukan. 


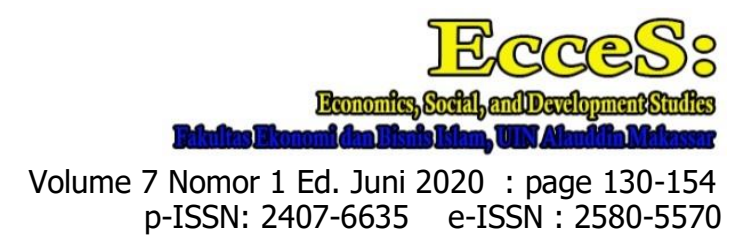

Laporan realisasi PMDN dari sebuah perusahaan, tentunya berasal nilai capaian dari deklarasi penanaman modal yang telah terwujud. Setidaknya realisasi PMDN tersebut akan menyampaikan informasi berupa besaran nilai penanaman modal dan tenaga kerja yang terserap. Hasil filter penelusuran pada database aplikasi SIMYaniz yang menjadi bahan masukan dalam pengolahan capaian realisasi PMDN di tahun 2015, diperoleh hasil bahwa beberapa perusahaan belum operasional akan tetapi sudah dimasukkan nilai realisasi PMDN-nya.

3. Pemasukan data perusahaan yang sama

Perusahaan terwaralaba dapat mendirikan cabang-cabang sesuai hasil kontrak kerja dengan mitra usaha. Terkait pencatatan realisasi penanaman modal dilakukan terhadap mitra usaha perusahaan terwaralaba. Hal ini disebabkan nilai investasi perusahaan terwaralaba seharusnya dicatatkan pada wilayah dimana kantor pusat perusahaan terwaralaba berdiri. Adapun wilayah dimana mitra usaha perusahaan terwaralaba berdiri mencatatkan nilai investasi dari mitra usaha bukan nilai investasi perusahaan terwaralaba.

Pencatatan realisasi PMDN perusahaan terwaralaba selain tidak sesuai penempatan wilayahnya maka pencatatan berulang dengan besaran investasi dan tenaga kerja yang sama juga menyebabkan nilai kredibilitas laporan capaian realisasi PMDN sangat rendah. Di Kabupaten Jombang pada 2015 terdapat sebuah perusahaan terwaralaba yang memilik mitra usaha di tiga lokasi yang seharusnya dalam laporan realisasi PMDN yang dicatatkan adalah besaran penanaman modal adalah tiap-tiap mitra usaha tersebut, bukan perusahaan terwaralaba.

4. Modal Kantor Pusat dimasukan dalam realisasi PMDN

Perusahaan yang telah berdiri suatu wilayah dan menetapkan lokasi usahanya tersebut sebagai kantor pusat perusahaan dapat mendirikan kantor cabang perusahaan di seluruh wilayah Indonesia. Persyaratan pendirian kantor cabang telah diatur sebagaimana ketentuan dalam Permendag 46/2009. Nilai penanaman modal yang dilakukan perusahaan di kantor pusat tentu berbeda dengan di kantor cabang. Untuk mempermudah dalam administrasi keuangan dan perpajakan umumnya dilakukan pemisahan sehingga dapat diketahui besaran investasi yang dilakukan antara kantor pusat dan kantor cabang. Terkait permasalahan hal tersebut perusahaan sebagaimana hasil screenshoot dari filter database hasil pengunduhan dari aplikasi SIMYaniz, seyogyanya tidak dimasukan dalam capaian realisasi PMDN di Kabupaten Jombang. 
Hal menarik berikutnya dari gambar sebelumnya, pada 2018 capaian realisasi PMDN di Kabupaten Jombang menjadi yang terendah selama periode tahun 2010-2018. Capaian realisasi PMDN pada 2018 yang hanya mencapai Rp. 310.297.594.103,- turun Rp. 104,764,634,108,- dibangdingkan tahun 2017 atau mencapai 25 \%. Faktor kualitatif yang secara umum menjadi penyebab turunnya capaian realisasi PMDN pada 2018 adalah capaian realisasi PMDN di Provinsi Jawa Timur yang secara umum menurun. Data yang dirilis BKPM jumlah realisasi PMDN di Provinsi Jawa Timur tahun 2018 hanya mencapai 33,3 triliyun rupiah atau turun 26 persen dari tahun 2017 dengan capaian realisasi PMDN yang mencapai 45 triliyun rupiah. Selain faktor secara makro tersebut, setidaknya terdapat beberapa faktor yang menyebabkan terjadinya penurunan capaian realisasi PMDN di Kabupaten Jombang, antara lain: Pertama, Penerapan Online Single Submission (OSS). OSS merupakan kebijakan baru dalam pelaksanaan perizinan berusaha yang berlaku secara nasional. Dilaksanakan berdasarkan Peraturan Pemerintah Nomor 24 Tahun 2018 tentang Pelayanan Perizinan Berusaha Terintegrasi Secara Elektronik, mengharuskan pemangku kewenangan perizinan baik di tingkat pusat dan daerah untuk segera mensingkronkan proses pelayanan perizinannya dengan membuat peraturan teknisnya di masing-masing tingkatan dan melaksanakan implementasi penerapan OSS. Pemerintah Kabupaten Jombang melalui DPM PTSP Kabupaten Jombang segera mengimplementasikan penerapan OSS dalam pemrosesan izin berusaha. Penerapan OSS di DPM PTSP Kabupaten Jombang secara tidak langsung menon-operasionalkan aplikasi SIMYaniz yang selama ini menjadi tulang punggung dalam memproses pelayanan perizinan. Dengan penerapan OSS maka tidak ada inputan pada aplikasi SIMYaniz sehingga tidak ada data perizinan berusaha yang dapat diolah dari SIMYaniz. Menjadi permasalahan lanjutan dimana input data yang dilakukan pelaku usaha di OSS tidak dapat dilakukan proses pengunduhan bahkan oleh level admin di tingkat kabupaten.

Kedua, minimnya industri padat modal yang berinvestasi. Kompilasi data yang dilakukan sebelum penerapan OSS dan setelah penerapan OSS di DPM PTSP tidak diperoleh adanya industri padat modal yang melakukan investasi di Kabupaten Jombang. Realisasi PMDN terbesar yang dicatatkan adalah pendirian perusahaan di wilayah Kecamatan Bareng yang berinvestasi dibidang Industri pembuatan kertas dan packing box dengan nilai sebesar 15 milyar rupiah.

Ketiga, deregulasi peraturan perundang-undangan. Efek samping dari penerapan OSS adalah perubahan beberapa peraturan perundang-undangan khususnya terkait perizinan. 


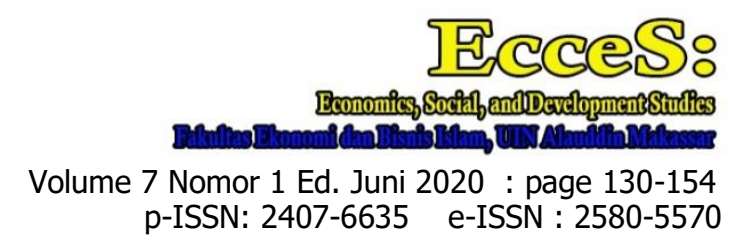

Perubahan peraturan perundang-undangan yang terjadi tidak hanya menyangkut perubahan mekanisme dan prosedur perizinan akan tetapi juga menyangkut tidak berlakunya beberapa izin yang sebelum penerapan OSS berlaku. Salah satu izin yang tidak berlaku setelah PP 24/2018 diberlakukan adalah izin gangguan (HO). Dalam ketentuan pendaftaran HO pelaku usaha harus mencantumkan besaran nilai investasi yang dilakukan termasuk di dalamnya memuat penggunaannya. Dalam penyusunan data capaian realisasi PMDN data HO menjadi data pembanding. Data HO disandingkan dengan data izin berusaha yang diajukan pelaku usaha.

\section{Penyusunan Data Realisasi PMDN Tahun 2019}

Penyampaian data realisasi PMDN oleh pelaku usaha melalui LKPM online yang terpantau hingga 30 September 2019 atau Tribulan 3 Tahun 2019 masih sangat minim sehingga dalam penyusunan laporan realisasi PMDN yang diselenggarakan oleh DPM PTSP Kabupaten Jombang masih berbasis pengolahan data perizinan berusaha. Hal yang membedakan adalah penyusunan data realisasi PMDN berbasis perizinan berusaha ini menggunakan basis data dari sistem OSS. Berbeda dengan tahun 2018 saat pertama kali sistem OSS berjalan, dimana sistem OSS baru bisa mengakomodasi laporan perizinan berusaha pada akhir tahun, maka di tahun 2019 sistem OSS telah menfasilitasi laporan perizinan berusaha di tiap bulannya. Data perizinan berusaha dari sistem OSS ini menjadi acuan DPM PTSP Kabupaten Jombang untuk menyusun laporan realisasi PMDN.

Laporan realisasi PMDN yang disampaikan oleh DPM PTSP Kabupaten Jombang hingga tribulan 3 Tahun 2019 terdapat 302 perusahaan PMDN yang mendaftar dengan 722 tenaga kerja yang terserap dengan capaian nilai realisasi investasi sebesar Rp. 43.040.032.361,-Pada periode yang sama di Tribulan 3 Tahun 2018 tercatat 890 perusahaan PMDN yang mendaftar dengan 5.488 tenaga kerja yang terserap dengan capaian nilai realisasi investasi sebesar Rp. 299.868.806.461,-. Memperhatikan data capaian realisasi PMDN sebagaimana diatas maka terdapat penurunan yang signifikan dari capaian realisasi PMDN di Kabupaten Jombang pada tahun 2019 apabila dibandingkan dengan tahun 2018. Gambar yang ada menunjukkan perbandingan capaian realisasi PMDN pada tribulan ketiga di setiap tahunnya. 
Gambar 5. Capaian Realisasi PMDN Triwulan 3 Tahun 2018 dan Triwulan 3 pada 2019 PERBANDINGAN REALISASI PMDN T-3 2018 DAN T-3 2019

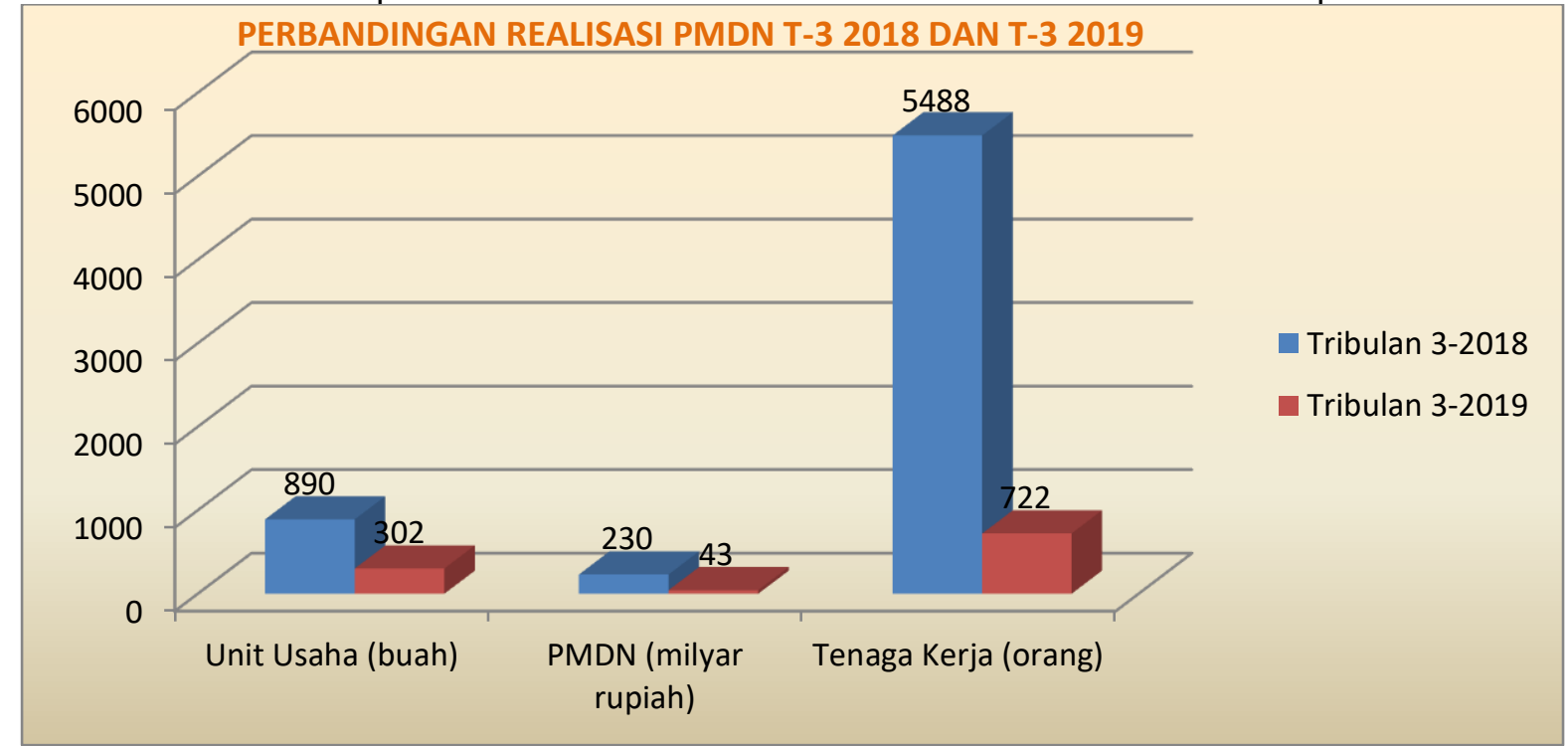

Sumber: Hasil Pengolahan Data Capaian Realisasi PMDN Kabupaten Jombang

Penurunan hasil rekapitulasi realisasi capaian PMDN disebabkan karena basis pengolahan data menggunakan data yang bersumber dari sistem OSS. Dengan sumber data dari sistem OSS maka data bersifat terpusat di BKPM, sehingga validasi data dilakukan secara berjenjang yaitu oleh DPM PTSP Kabupaten, DPM PTSP Provinsi dan BKPM.

Penggunaan data perizinan berusaha walaupun belum sesuai kaidah ketentuan peraturan perundang-undangan yang berlaku dalam penyusunan penyusunan data capaian realisasi PMDN oleh DPM PTSP Kabupaten Jombang di Tahun 2019, akan tetapi melihat proses validasi yang dilakukan secara berjenjang maka realisasi PMDN dapat digambarkan besarannya. Kelemahan penggunaan data perizinan berusaha adalah tidak menggambarkan perkembangan capaian realisasi secara berkala dari pelaku usaha, akan tetapi berupa deklarasi investasi awal dari pelaku usaha. Sehingga nilai perkembangan berkala dari deklarasi investasi awal tersebut tidak terdata dan/atau benar-benar terealisasi seluruhnya ataukah belum.

\section{Implikasi Penyusunan Data Capaian Realisasi PMDN}

Implementasi kebijakan prinsipnya adalah merupakan suatu metode supaya sebuah kebijakan yang diambil dapat mencapai tujuannya. Penyusunan Data Realisasi PMDN oleh Dinas Penanaman Modal dan Pelayanan Terpadu Satu Pintu Kabupaten Jombang merupakan amanat dari Peraturan Menteri Dalam Negeri Nomor 54 Tahun 2010 Tentang Pelaksanaan Peraturan Pemerintah Nomor 8 Tahun 2008 Tentang Tahapan, Tatacara Penyusunan, Pengendalian, dan Evaluasi Pelaksanaan Rencana Pembangunan Daerah, yang merupakan sebuah aturan pelaksana bagi pemerintah daerah diterbitkan dengan tujuan menjadi 


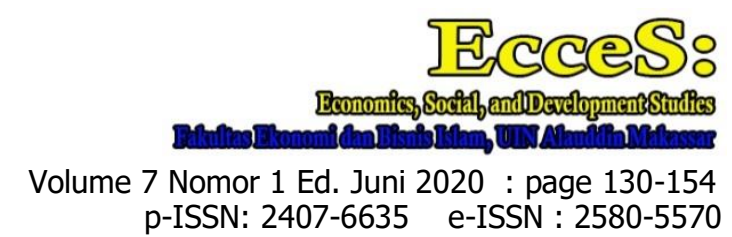

pedoman bagi pemerintah daerah untuk menyusun dan mempublikasikan besaran investasi yang terjadi di daerahnya. Dalam upaya mencapai tujuan tersebut maka pemerintah daerah harus melakukan perhitungan dengan seksama yaitu total investasi PMDN diperoleh dari nilai proyek yang teralisasi, sehingga apabila investor belum melaksanakan realisasi komitmen yang tertuang di izin prinsip atau pendaftaran penanaman modal maka belum dapat dikatakan sebagai proyek yang sudah berjalan. Implementasi Permendagri 54/2010 di Kabupaten Jombang dalam praktiknya tidak bisa berjalan dengan sempurna karena dalam penyusunan data capaian realisasi PMDN, DPM PTSP selaku operator tidak melakukan proses verifikasi besaran realisasi PMDN yang benar-benar sudah terealisasi.

Pemerintah Kabupaten Jombang melalui DPM PTSP dalam penyusunan data capaian realisasi PMDN seharusnya melakukan proses pengkajian yang mendalam, melakukan verifikasi dan validasi data sebelum laporan tersebut disusun kemudian dipublikasikan. Penggunaan data perizinan berusaha dalam penyusunan data capaian realisasi PMDN menambahkan permasalahan baru terkait validitasnya. Seharusnya penggunaan data perizinan berusaha digunakan dalam laporan perkembangan perizinan berusaha bukan sebagai laporan realisasi PMDN. Sehingga dengan berbagai permasalahan dalam penyusunan data capaian realisasi PMDN yang terjadi tersebut, serta disarikan dari informasi yang didapatkan dalam penelitian yang dilakukan maka penyusunan realisasi PMDN yang tidak memperhatikan kaidah yang benar akan menimbulkan permasalahan antara lain: Pertama, kesalahan dalam pengambilan kebijakan oleh pemerintah terutama terkait kebijakan di sektor penanaman modal. Sebagai salah satu item dalam penyusunan Produk Domestik Regional Bruto (PDRB) maka nilai capaian realisasi menjadi sangat krusial peranannya. Data yang memiliki tingkat validasi yang rendah berpengaruh besar terhadap penyelenggaraan dan pengambilan kebijakan yang dilakukan oleh pemerintah daerah; Kedua, gambaran semu perkembangan realisasi PMDN, nilai investasi yang didata tanpa melakukan verifikasi dan validasi terhadap besaran realiasi PMDN yang terjadi, menggambarkan jumlah yang tidak sesuai dari keseluruhan pencatatan dan penyusunan yang dilakukan. Implikasi awal yang terjadi adalah nilai capaian realisasi PMDN yang dicatatkan lebih rendah dari hasil pengolahan dan penyusunan data yang dilakukan; Ketiga, penurunan kredibilitas pemerintah daerah, data capaian realisasi PMDN yang disusun dan dipublikasikan tanpa adanya proses verifikasi dan validasi yang ketat apabila data tersebut diindikasikan memiliki validasi rendah akan membawa dampak terhadap kredibilitas pemerintah daerah oleh publik. Masyarakat luas akan beranggapan bahwa pemerintah 
daerah tidak memiliki keseriusan dalam penyusunan data capaian realisasi PMDN padahal sebagaimana diketahui data tersebut sangat penting dalam rangka menggambarkan kondisi perekonomian suatu wilayah.

Implikasi penyusunan capaian realisasi PMDN yang begitu besar dan luas dampaknya kepada publik, maka seharusnya Pemerintah Kabupaten Jombang dalam kegiatan tersebut benar-benar memperhatikan kaidah peraturan sesuai ketentuan yang ada. Menerapkan Peraturan BKPM Nomor 7 Tahun 2018 tentang Pedoman dan Tata Cara Pengendalian Pelaksanaan Penanaman Modal dalam menyusun data capaian realisasi PMDN akan mengurangi kesalahan. Penggunaan Laporan Kegiatan Penanaman Modal (LKPM) merupakan solusi utama dalam penyusunan laporan realisasi PMDN. Karena basis data LKPM merupakan sumber data yang memberikan gambaran sesungguhnya dari perkembangan realisasi PMDN yang telah diwujudkan oleh pelaku usaha. Selanjutnya dengan mengkaji secara sederhana kesalahan dalam penyusunan laporan realisasi PMDN yang dilakukan oleh DPM PTSP Kabupaten Jombang sebagaimana uji petik yang dilakukan pada tahun 2015 maka tingkat kesalahan yang terjadi dapat mencapai $70 \%$ untuk itu perlu langkah kongkrit dari pihak berkepentingan dalam upaya melakukan pembenahan dalam penyusunan data capaian realisasi PMDN di Kabupaten Jombang.

\section{KESIMPULAN / CONCLUSSION}

Berdasarkan uraian sebelumnya, dapat disimpulkan bahwa data sumber dalam penyusunan laporan realisasi PMDN yang dilaksanakan oleh Dinas Penanaman Modal dan Pelayanan Terpadu Satu Pintu Kabupaten Jombang diambil dari data penyelenggaraan perizinan berusaha yang berproses dan diterbitkan. Penggunaan Laporan Kegiatan Penanaman Modal (LKPM) sebagai media verifikasi dan validasi data dalam proses penyusunan laporan realisasi PMDN tidak dapat dilakukan oleh Dinas Penanaman Modal dan Pelayanan Terpadu Satu Pintu Kabupaten Jombang dikarenakan belum berjalannya pelaporan oleh perusahaan melalui media LKPM online ataupun pelaporan secara manual. Dalam penyusunan data capaian laporan realisasi PMDN oleh Dinas Penanaman Modal dan Pelayanan Terpadu Satu Pintu Kabupaten Jombang dilakukan metode filter data terhadap data perizinan berusaha. Sedangkan dalam verifikasi dan validasi data realisasi penanaman modal kepada setiap pelaku usaha tidak mungkin dilakukan dikarenakan keterbatasan jumlah personil dengan sebaran kegiatan usaha yang luas dengan jumlah yang besar di seluruh wilayah Kabupaten Jombang. 


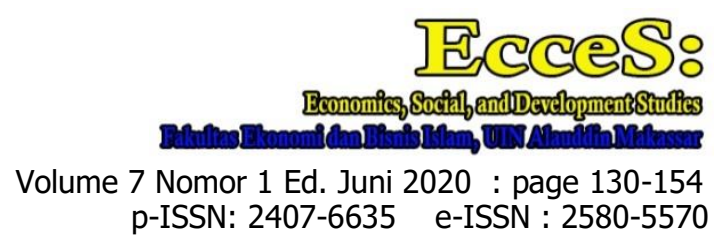

\section{DAFTAR PUSTAKA / REFERENCES}

Abib, Agus Saiful, Ani Triwati, Muhammad Iftar Aryaputra. 2016. Peranan Undang-Undang Nomor 25 Tahun 2007 Tentang Penanaman Modal Dalam Upaya Menstimulasi Pertumbuhan Investasi di Provinsi Jawa Tengah Guna Menyongsong Globalisasi Dunia. Jurnal Dinamika Sosial Budaya, Volume 18 Nomor 2, Desember 2016.

Ambarita, F. 2012. Analisis Perkembangan Incremental Capital Output Ratio (ICOR) Sektor Industri Provinsi Daerah Istimewa Yogyakarta Tahun 2001 - 2008. Tesis. Yogyakarta: UPN Veteran.

Asiyan, Sri. 2013. Pengaruh Penanaman Modal Dalam Negeri, Penanaman Modal Asing dan Ekspor Terhadap Pertumbuhan Ekonomi Jawa Timur. Jurnal Pendidikan Ekonomi. Volume 1 Nomor 3 Tahun 2013.

Aulia, Anisa. 2013. Analisis Pengaruh Ekspor Neto, Inflasi, PMA dan PMDN Terhadap Pertumbuhan Ekonomi Indonesia Periode 2000-2012. Skripsi. FEB UIN Syarief Hidayatullah. Jakarta.

BPS. 2017. Kabupaten Jombang Dalam Angka (Jombang Regency in Figures) 2017. BPS Kabupaten Jombang.

BPS. 2017. Statistik Daerah Kabupaten Jombang 2017. BPS Kabupaten Jombang

Cahyono, Hendry dan Siska Anggraini Putri. 2017. Pengaruh PMDN, PMA dan Belanja Daerah Jawa Timur Terhadap Pertumbuhan Ekonomi di Kota Surabaya dan Kabupaten Banyuwangi. Media Trend. Volume 12 (1) 2017. Halaman 63-75.

Candra, Eddy Wibowo. 2012. Analisis Peranan Pengeluaran Pemerintah, Tenaga Kerja Dan Penanaman Modal Dalam Negeri (PMDN) Terhadap Pertumbuhan Ekonomi Provinsi Jawa Timur 2001-2010. Universitas Brawijaya. Malang.

Deliarnov. 2010. Perkembangan Pemikiran Ekonomi. Jakarta: Rajawali Press.

Haryanto, J. 2005. Analisis Hubungan Antara Pertumbuhan Ekonomi dan Investasi Pemerintah di Kabupaten Musi Banyuasin. Kajian Ekonomi, 4(1):56-80.

Hessel, Nagi. 2005. Manajemen Publik. Jakarta: PT. Gramedia Widiasarana.

Humaini, Hayatullah, M. Safri, dan Etik Umiyati. 2007. Analisis Penanaman Modal Dalam Negeri dan Penanaman Modal Asing dan Pengaruhnya terhadap Pertumbuhan Ekonomi Provinsi Jambi. Jurnal Perspektif Ekonomi dan Pembangunan Daerah. Volume 6. No. 2, Mei-Agustus 2017.

Ilham, M. 2013. Analisis Pengaruh Pengeluaran Pemerintah Kota, ICOR, Investasi Terhadap Perekonomian Daerah Kota Tebing Tinggi. Tesis. Medan: Sekolah Pascasarjana Universitas Sumatera Utara. 
Raco, J. R. 2013. Metode Penelitian Kualitatif Jenis Karakteristik dan Keunggulannya. Grasindo. Jakarta.

Keban, T. Yeremias. 2004. Enam Dimensi Strategis Administrasi Publik, Konsep, Teori dan Isu. Yogyakarta: Gava Media.

Maharani, Dewi. 2016. Analisis Pengaruh Investasi dan Tenaga Kerja terhadap Produk Domestik Regional Bruto (PDRB) di Sumatera Utara. Intiqad. Vol. 8 No. 2 Desember 2016.

Mahrisa, Tevi dan Syamsul Amar B. 2019. Pengaruh Investasi dalam Negeri, Investasi Asing, Tenaga Kerja dan Infrastruktur terhadap Perekenomian di Provinsi Sumatera Barat. Jurnal Kajian EKonomi dan Pembangunan. Volume 1, Nomor 3, Agustus 2019. halaman 691-704.

Malau, Alfencius Mulatua. I Made Sudarma, I Nyoman Gede Ustriyana. 2015. Pengaruh Penanaman Modal Dalam Negeri dan Penanaman Modal Asing Terhadap PDRB Sektor Pertanian di Provinsi Bali. Jurnal Agribisnis dan Agrowisata. Vol. 4, No. 5, Desember.

Mankiw N, Gregory, dkk. 2012. Pengantar Ekonomi Makro. Jakarta: Salemba Empat.

Miles, Matthew dan Huberman, A. Michael. 1992. Analisis Data Kualitatif: Tentang MetodeMetode Baru. Jakarta: UI Press.

Mokodompis, Rafika., Vekie Rumate, Mauna Maramis. 2014. Pengaruh Tingkat Investasi Dan Tenaga Kerja Terhadap Pertumbuhan Ekonomi (Studi Pada Kota Manado Tahun 20032012). Jurnal Berkala Efisiensi. IEP - FEB Unsrat Manado.

Moleong, Lexy J. 2005. Metodologi Penelitian Kualitatif. Bandung: Remaja Rosdakarya.

Peraturan BKPM Nomor 7 Tahun 2018 tentang Pedoman dan Tata Cara Pengendalian Pelaksanaan Penanaman Modal.

Peraturan Bupati Jombang Nomor 16 Tahun 2018 tentang Pelimpahan Wewenang Penyelenggaraan Perizinan kepada Dinas Penanaman Modal dan Pelayanan Terpadu Satu Pintu Kabupaten Jombang sebagaimana telah dirubah dengan Peraturan Bupati Jombang Nomor 36 Tahun 2018.

Peraturan Bupati Kabupaten Jombang Nomor 61 Tahun 2018 Tentang Kedudukan, Susunan Organisasi, Tugas Pokok dan Fungsi Serta Tata Kerja Dinas Penanaman Modal dan Pelayanan Terpadu Satu Pintu Kabupaten Jombang.

Peraturan Daerah Kabupaten Jombang Nomor 8 Tahun 2016 Tentang Pembentukan dan Susunan Perangkat Daerah Kabupaten Jombang.

Peraturan Menteri Dalam Negeri Nomor 100 Tahun 2016 Tentang Pedoman Nomenklatur Dinas Penanaman Modal dan Pelayanan Terpadu Satu Pintu Provinsi dan Kabupaten/Kota. 


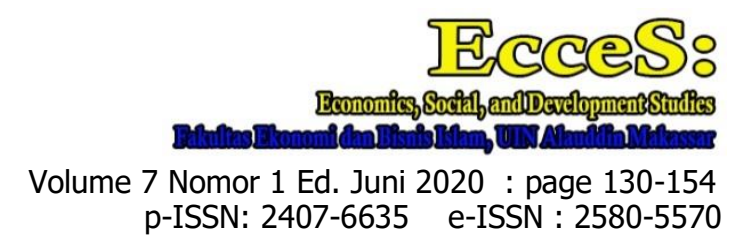

Peraturan Menteri Dalam Negeri Nomor 54 Tahun 2010 Tentang Pelaksanaan Peraturan Pemerintah Nomor 8 Tahun 2008 Tentang Tahapan, Tatacara Penyusunan, Pengendalian, dan Evaluasi Pelaksanaan Rencana Pembangunan Daerah.

Prasetyo, Eko. 2011. Analisis Pengaruh Penanaman Modal Dalam Negeri (PMDN), Penanaman Modal Asing (PMA), Tenaga Kerja, dan Ekspor Terhadap Pertumbuhan Ekonomi di Jawa Tengah Periode Tahun 1985-2009. Skripsi. Jurusan Ekonomi Pembangunan. Fakultas Ekonomi. Universitas Negeri Semarang.

Prasetyo, P. Eko. 2009. Fundamental Makro Ekonomi. Yogyakarta: Beta Offset.

Rustiono, Deddy. 2008. Analisis Pengaruh Investasi, Tenaga Kerja, dan Pengeluaran Pemerintah Terhadap Pertumbuhan ekonomi Jawa Tengah Periode Tahun 1985-2006. Tesis. Semarang: Fakultas Ekonomi Universitas Diponegoro.

Saleh, I, H. Varmazyari, and H. Moslemzadeh. 2008. Investigation the Potential of Investment in Agricultural Sector of Iran (Emphasizing on National Development Programs). American - Eurasian J. Agric. \& Environ. Sci. 2 (Supple 1) : 108 - 112.

Setyowati, Eni dan Siti Fatimah. 2007. Analisis Faktor-Faktor yang Mempengaruhi Investasi Dalam Negeri di Jawa Tengah 1980-2002. Jurnal Ekonomi Pembangunan Vol. 8 No. 1, Juni 2007 Hal. 62-84.

Skousen, Mark. 2009. Sejarah Pemikiran Ekonomi Sang Maestro: Teori-Teori Ekonomi Modern. Prenada Media Group.

Tambunan, Tulus. 2001. Perekonomian Indonesia: Teori dan Temuan Empiris. Jakarta: Ghalia Indonesia.

Undang-Undang Nomor 25 Tahun 2007 Tentang Penanaman Modal.

Vercellis, Carlo. 2011. Business Intelligence: Data Mining and Optimization for Decision Making. Chichester: John Wiley \& Sons.

Yunarko, Arif (2007). Analisis Pengaruh Tingkat Investasi, Pendapatan Asli Daerah dan Tenaga Kerja terhadap Produk Domestik Regional Bruto Jawa Tengah. Skripsi. Jurusan Ekonomi Pembangunan, Fakultas Ekonomi Universitas Negeri Semarang. 